\title{
RESOURCE-EFFICIENT METHOD OF WALL ERECTION IN INDIVIDUAL HOUSING CONSTRUCTION USING POLYMER TUBE CONFINED CONCRETE
}

\author{
Andrei Naumov ${ }^{1}$, Aleksandr Dolzhencko², Maria Krutilova ${ }^{3}$, Nikolay Simonov ${ }^{4}$ \\ 1,2,3,4 Shukhov Belgorod State Technological University \\ Kostyukova St., 46, Belgorod, Russia \\ ${ }^{3}$ Corresponding author: marykrutilova@gmail.com
}

\begin{abstract}
Introduction: The paper analyzes an experimental load-bearing structure of hybrid cast-in-place and precast lowrise residential buildings using wall panels with polymer tube confined concrete elements. Due to the improvement of design and process solutions, it is possible to decrease the cost, reduce the material and resource intensity of individual housing construction, ensuring structural safety and long life of such buildings. Methods: The authors propose a method of manufacturing wall panels, involving industrial production of retained formworks made of polymer tubes and oriented strand board, as well as their subsequent assembly and concreting at a construction site. Results and discussion: Results of the study were provided to the New Technologies and Materials in Construction interdepartmental team of the Belgorod Region Department of Construction and Transport. The proposed method is recommended for testing at sites of individual housing construction in the Belgorod agglomeration, including construction financed from the budget.
\end{abstract}

\begin{abstract}
Keywords
Polymer tube confined concrete, tube confined concrete, retained formwork, frame construction, lightweight concrete.
\end{abstract}

\section{Introduction.}

Modern resource-efficient building structures used in construction engineering - mainly in individual housing construction - are intended to meet social needs of the industry, which define key priorities of individual housing construction: cost-efficiency, reliability, and rapid erection. Innovative building products and technologies are a key aspect in improving the efficiency of individual housing construction in terms of the key priorities and sustainable development of the industry. Such products and technologies decrease the negative impact of the following production factors in construction:

- one-size-fits-all technical solutions, which result in a significant excess consumption of construction resources (in comparison with the minimum acceptable consumption);

- large volumes of highly-skilled manual labor when the standard quality of building products is ensured;

- high costs for the prevention and elimination of manufacturing defects in building products;

- high transportation costs for the delivery of building structures to a construction site.

The rational design of elements for individual residential buildings and the development of a corresponding erection technology alleviate these problems most efficiently. Such elements shall feature the following:
- rational material distribution in accordance with internal forces arising in an element under standard loads;

- universal character of building elements' formation and corresponding spatial and planning solutions;

- maximum prefabrication degree with factory production control;

- structural simplicity and flaw tolerance in case of poor installation;

- use of common, available and cheap resources.

As for individual housing construction, load-bearing wall structures are characterized by the largest volume, highest cost, installation labor intensity, and susceptibility to defects. Both vertical and horizontal loads (caused by wind pressure, non-uniform loading on floor slabs, lateral earth pressure on foundation walls, complex configuration of walls in a plan of a building) are typical for wall structures.

\section{Methods, results and discussion.}

Earlier, the authors studied the strength and stressstrain performance of polymer tube confined concrete (PTCC) elements carrying vertical and horizontal loads typical for walls, representing $P P$ and $P E$ industrial tubes filled with heavyweight concrete, common in engineering construction. According to the results of experimental studies, under axial compression of short PTCC columns (with an OD of $110 \mathrm{~mm}$ and a height of 400 $\mathrm{mm}$ ) filled with B15 concrete (with manual compaction), 
Andrei Naumov, Aleksandr Dolzhencko, Maria Krutilova, Nikolay Simonov- Pages 38-43

a significant increase in cylinder strength (up to $35 \%$ in comparison with cube strength for the same quality of concrete) as well as a higher integrity and improved monolithic structure of the concrete core are observed (Shevchenko, Naumov, Dolzhenko, 2015a, 2015b). The horizontal displacements of the PTCC column structure being a part of an above-ground wall were $13 \%$ less than the horizontal displacements of the equivalent structure without a casing. When a foundation structure subject to lateral passive earth pressure was modeled, the horizontal displacements of the PTCC column decreased by $7 \%$. Based on these results, we can put the reserve of the load-bearing capacity of PTCC columns in comparison with columns without a casing at $15 \%$ max in terms of hardness and $30 \%$ max in terms of strength. The reserve of the load-bearing capacity of PTCC walls, averaged for an actual building, shall be estimated closer to the upper threshold as the volume of above-ground walls even in a one-story building exceeds the volume of foundation.

Thus, the use of PTCC in wall structures for individual housing construction is a rational and innovative method of construction that meets the specified criteria of efficiency regarding individual housing construction and matches the behavior of wall elements to a large extent. The use of PTCC represents an efficient technical solution in wall construction, and the use of PTCC columns as a part of a wall is most efficient in combination with a wall filling with cast-in-place heat-insulation concrete and factory-finishing elements acting as a pre-fabricated formwork. The paper addresses methodological and process approaches to the development of an innovative technology for wall construction (in individual housing construction) based on the use of cast-in-place and precast framing constructed at a construction site in a pre-fabricated panel formwork made of large elements with constructed elements of the engineering infrastructure of a building.

The authors studied the resistance of short PTCC columns (with an OD of $110 \mathrm{~mm}$ and a height of $400 \mathrm{~mm}$ ) filled with B15 concrete (with manual compaction) under axial compression. The results of an analysis of samples obtained by sawing a short PTCC column into thin slices showed a high density of the concrete core.

According to the results of an axial load test, concrete cylinders are destructed in a standard way (their sides are crushed and longitudinal cracks appear), and the strength of PTCC columns in a PE casing is higher than that in cubes by $35 \%$ max, and higher than that in a PP casing by $15 \%$ max (Table 1 ).

To study the type and nature of the physical nonlinearity of the deformation in a polymer casing, the authors determined experimentally the deformation characteristics of PE in PTCC tubes using a WEW-600D universal hydraulic testing machine. The longitudinal and transverse strains were measured automatically with a $0.01 \%$ load step. Results of the tests are shown in Figure 1. The polymer casing in PTCC columns demonstrates a significant physical nonlinearity of stress-strain properties (Figure 2). The stress-strain modulus $E$ decreases from 1200 to 280 $\mathrm{MPa}$ with an increase in strain rate $(\varepsilon)$ up to $5.3 \%$.
Table 1. Axial load test of short PTCC columns

\begin{tabular}{|c|c|c|}
\hline No. & Ultimate load, $t$ & $\begin{array}{c}\text { Average bearing capacity, } \\
\mathrm{t}\end{array}$ \\
\hline 1 & 12.25 & 10.9 \\
\hline 2 & 9.75 & \\
\hline 3 & 10.75 & \\
\hline 4 & 16.5 & 14.7 \\
\hline 5 & 11.25 & \\
\hline 6 & 16.25 & \\
\hline 7 & 12.75 & \\
\hline 8 & 12.5 & \\
\hline 9 & 12.25 & \\
\hline
\end{tabular}

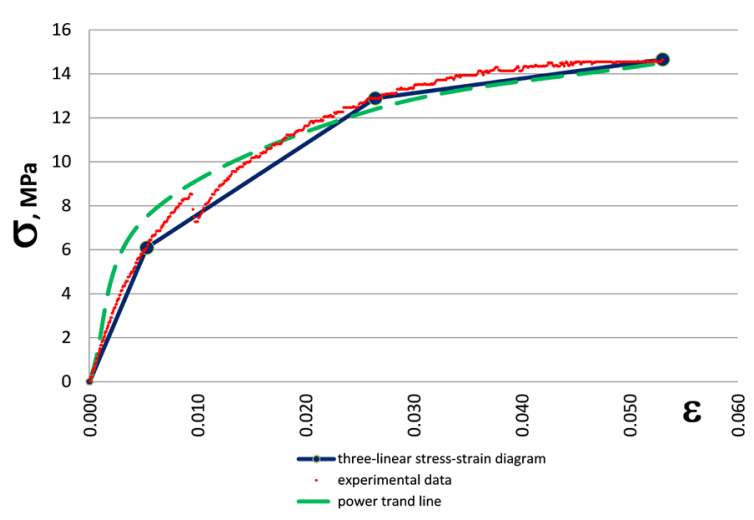

Figure 1. Stress-strain curve for a polymer casing (experimental data obtained by the authors).
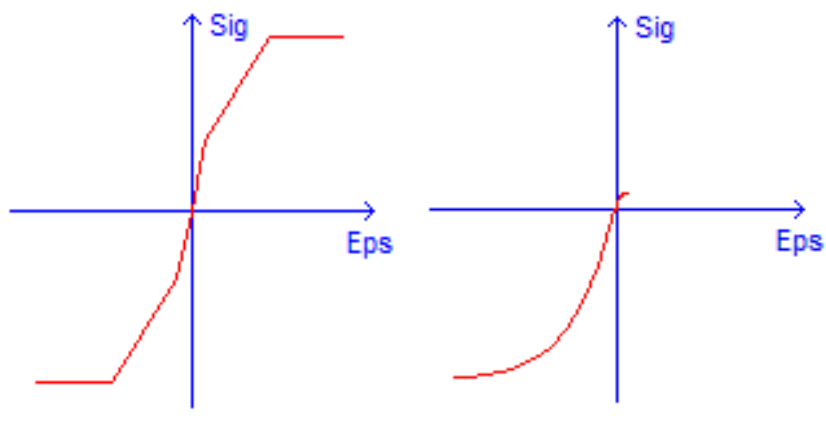

Figure 2. Exponential stress-strain curve for concrete (on the left) and three-line stress-strain curve for a polymer casing (on the right) used in FEM numerical simulation.

A universal wall panel made of oriented strand board (OSB) sheets combined through special intermediate 
elements with hollow plastic tubes installed inside the sheet at particular intervals and height represents a structural element of the proposed method (Figure 3).
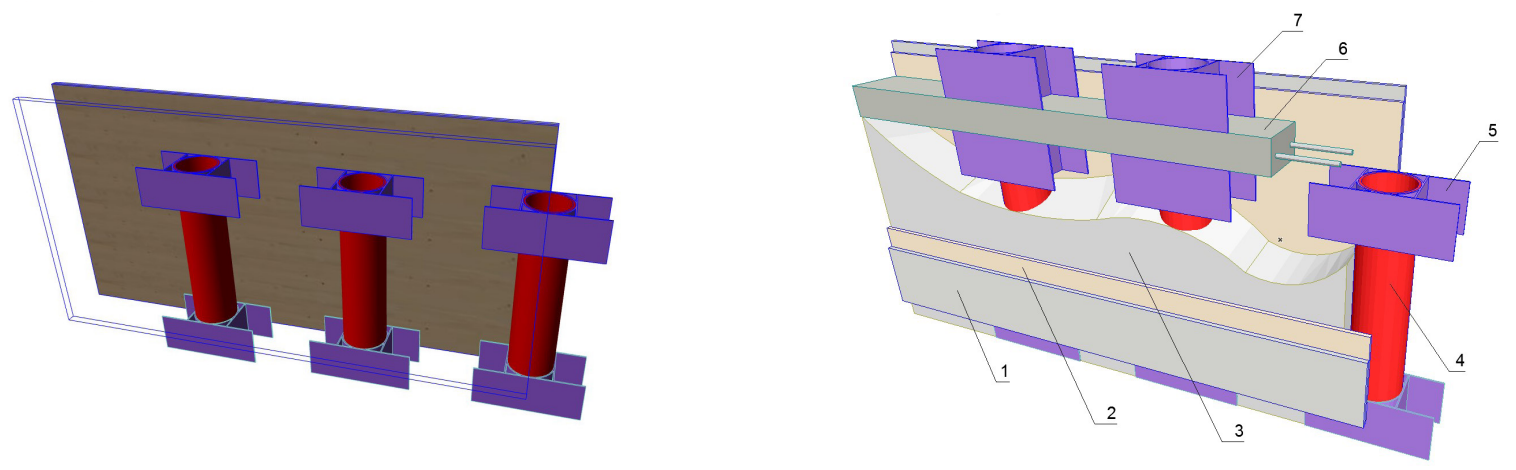

Figure 3. General view of a universal wall panel: on the left - a wall panel with plastic tubes (to be filled with concrete); on the right - a wall panel filled with concrete: 1 - interior finishing; 2 - an internal layer of OSB; 3 - heat insulation with precast foam concrete; 4 - a PTCC column; 5 - an intermediate element; 6 - a horizontal reinforcement frame in each tier of panels (made of precast heavyweight concrete); 7 - an intermediate element of the overlying tier of panels.

The process of wall construction as per the proposed method includes the following steps:

1) the panels are installed in tiers along the perimeter of inner and outer load-bearing walls; the panel sheets are joined with decorative vertical coupling elements (Figure 2);

2) the tubes are filled with heavyweight concrete of specified class; the PTCC columns are reinforced (if necessary) in accordance with the specified stress-strain state for each panel individually;

3) the space between the PTCC columns is filled with lightweight precast heat-insulation material (e.g. precast foam concrete or polystyrene concrete) below the bottom elevation of the horizontal reinforcement frame binding the panels along the perimeter (Figure 1);

4) a reinforcement cage is installed, heavyweight concrete to grout the horizontal reinforcement frame is filled below the bottom elevation of the intermediate elements of the overlying tier of panels;

5) wall panels of the next tier are installed in a staggered order (being shifted at a distance between two or three columns); the panel sheets of the adjacent tiers are joined with decorative horizontal coupling elements.
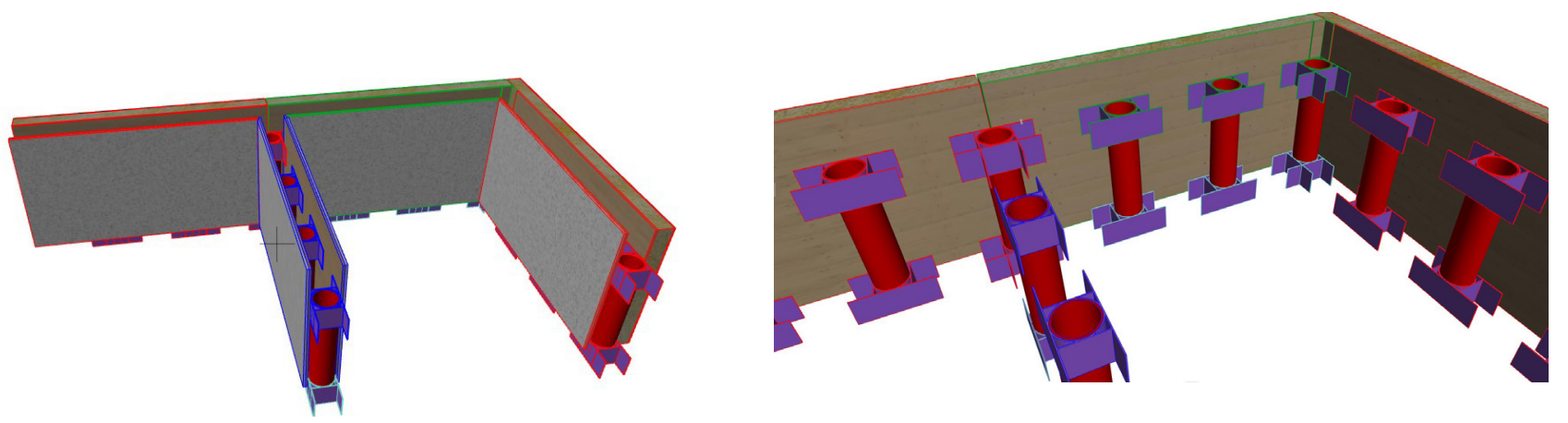

Figure 4. Wall panels installed in a tier (to be filled with concrete): on the left - sheets of internal and external prefabricated finishing; on the right - tubes of internal PTCC columns with installed intermediate elements.

Innovative intermediate elements made of plastic similar to that used in PTCC tubes and manufactured based on the extrusion technology are of particular interest. These universal elements can be adapted by cutting off unnecessary fragments (with subsequent recycling), which makes it possible to join panels in a tier horizontally in a wide range of joint combinations (Figure 3). Therefore, it is possible to use standard joint units and, using panels proposed, assemble internal and external wall structures of arbitrary rectangular configuration (Figure 4) that meets the requirements of various spatial and planning solutions in individual housing construction, preserving their maximum functionality and resource efficiency.

To ensure practical use of panels proposed and corresponding automated document management, the authors suggest a template for the identification of such panels, including basic data required by a manufacturer and provided by a designer / BIM program when automating the process of arranging wall panels in a plan of a building. 

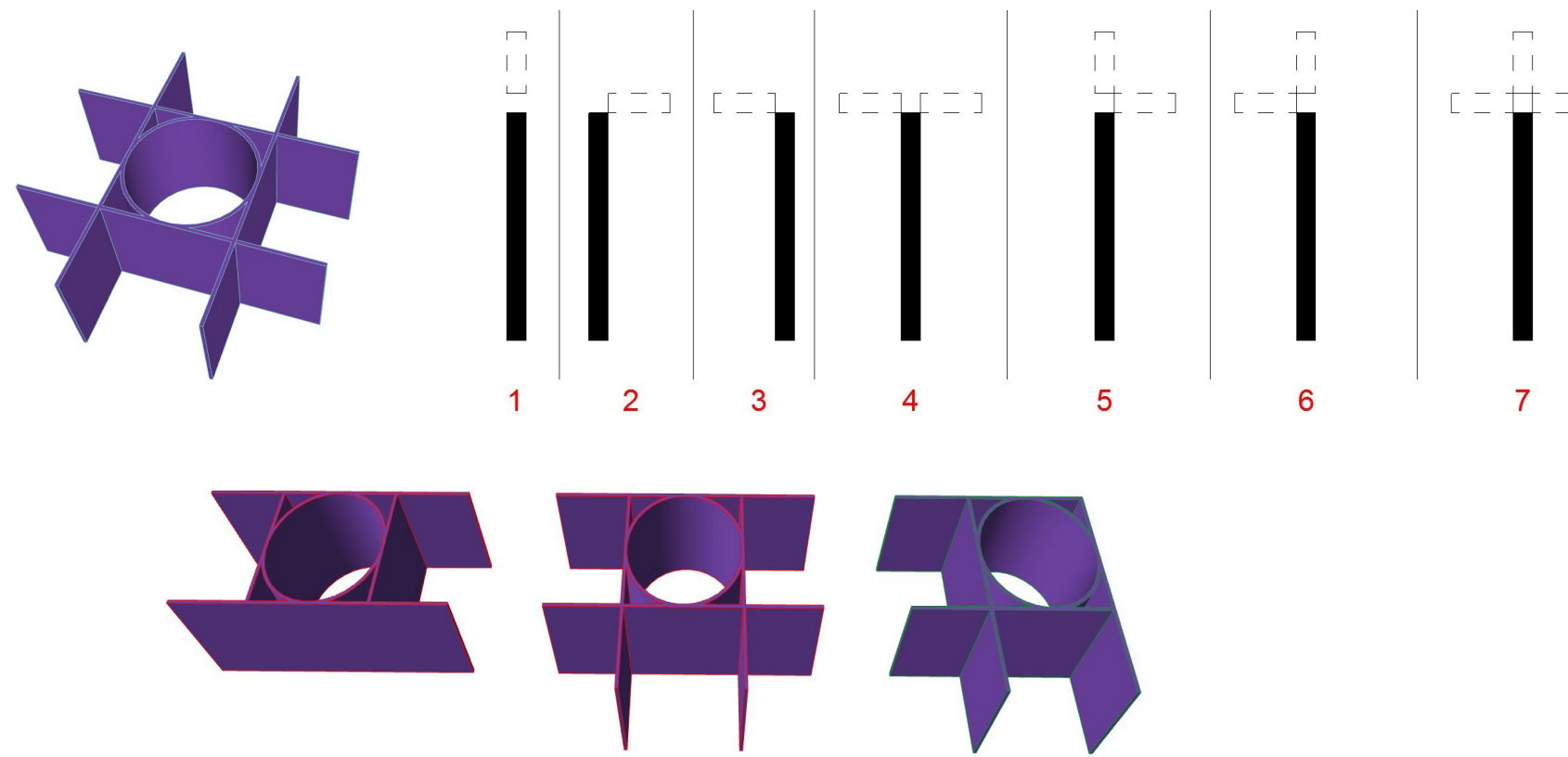

Figure 5. Universal intermediate element (on the left), options of joining wall panels horizontally in a tier using an adaptable intermediate element (on the right), and options of adapting an intermediate element to join panels in a tier as per different options (below).
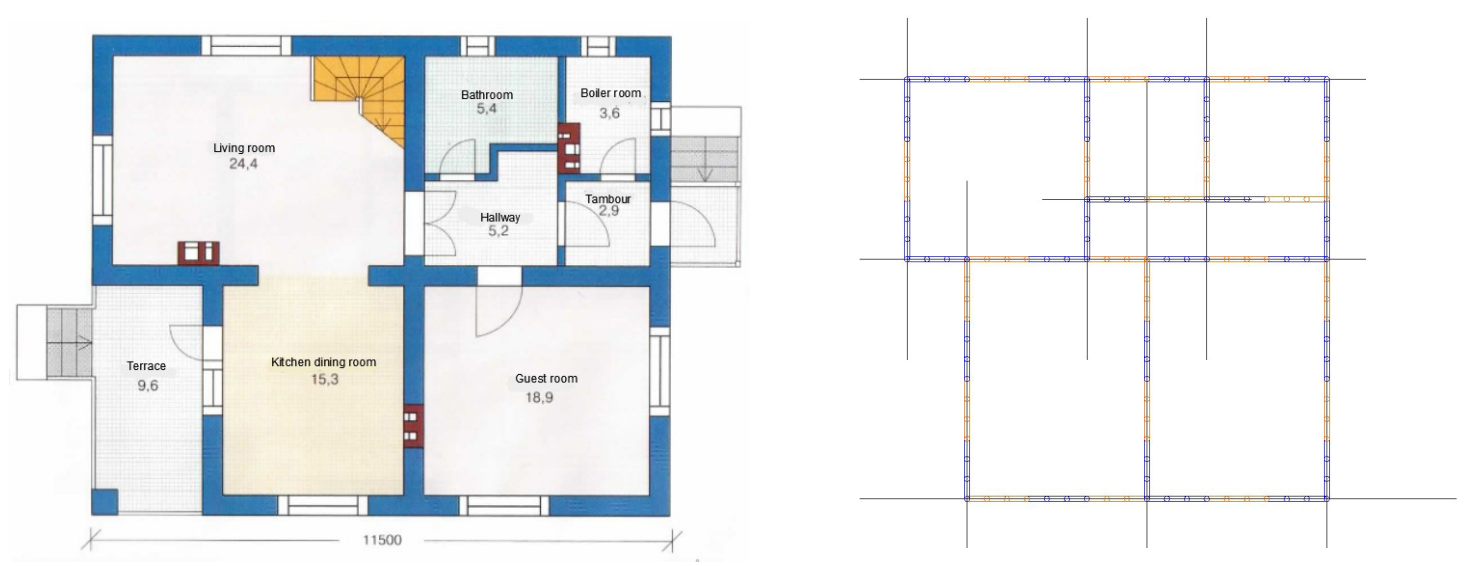

Figure 6. Floor plan of an individual residential building (on the left) and a layout of proposed wall panels during construction and installation (on the right).

\section{Conclusion.}

The proposed method is intended to be improved in terms of the detalization of coupling elements, insulation and finishing layers, method of applying prefabricated internal and external finishing materials, elements of utilities. Software algorithms for automation of building design with the use of proposed wall panels based on BIM technologies are developed. In general, the proposed method represents one of the options to use PTCC structures in resource-efficient individual housing construction, demonstrating that it is efficient and reasonable to use PTCC in construction engineering.

\section{Acknowledgments}

The study was performed under the flagship university development program at the premises of Shukhov Belgorod State Technological University 


\section{References}

Dolzhenko, A.V., Naumov, A.E., Shevchenko, A.V., Kara, K.A. (2017). Experimental study of actual operation of plastic tube concrete constructions. Advances in Engineering Research, Actual Issues of Mechanical Engineering (AIME 2017), 133, pp. 175-180. DOI: 10.2991/aime-17.2017.29.

Dolzhenko, A.V., Naumov, A.E., Shevchenko, A.E. (2018). Bearing capacity and rigidity of short plastic-concrete-tubal vertical columns under transverse load. IOP Conference Series: Materials Science and Engineering, 327, 042024. DOI: 10.1088/1757-899X/327/4/042024.

Huang, C.S., Yeh, Y.K., Liu, G.Y., Hu, H.-T., Tsai, K.-C., Weng, Y.-T., Wang, S.H., Wu, M.-H. (2002). Axial load behavior of stiffened concrete-filled steel columns. Journal of Structural Engineering, 128 (9), pp. 1222-1230. DOI: 10.1061/ (ASCE)0733-9445(2002)128:9(1222).

Kara, K.A., Dolzhenko, A.V., Zharikov, I.S. (2018). Influence of processing factors over concrete strength. IOP Conference Series: Materials Science and Engineering, 327, 032027. DOI: 10.1088/1757-899X/327/3/032027.

Luksha, L.K. (1977). Strength of tube confined concrete. Minsk: Vysheyshaya Shkola, 96 p.

Sakino, K., Nakahara, H., Morino, S., Nishiyama, I. (2004). Behavior of centrally loaded concrete-filled steel-tube short columns. Journal of Structural Engineering, 130 (2), pp. 180-188. DOI: 10.1061/(ASCE)0733-9445(2004)130:2(180).

Sanzharovsky, P. S. (2000). Theory and analysis of the strength and stability of structural elements made of steel tubes filled with concrete. DSc Thesis in Engineering.

Schneider, S.P. (1998). Axially loaded concrete-filled steel tubes. Journal of Structural Engineering, 124 (10), pp. 1125-1138. DOI: 10.1061/(ASCE)0733-9445(1998)124:10(1125).

Serykh, I.R., Chernyshova, E.V. (2014). Steel concrete in modern construction. High-Tech Technologies and Innovations. International Scientific-and-Practical Conference dedicated to the $60^{\text {th }}$ Anniversary of Shukhov Belgorod State Technological University. $21^{\text {st }}$ Scientific Readings. Belgorod: Shukhov Belgorod State Technological University, pp. 112-115.

Shevchenko, A.V., Naumov, A.E., Dolzhenko, A.V. (2015a). Effective tube confined concrete structures for individual housing construction. Economics, Science, Manufacturing: Collection of Scientific Papers, 28. Moscow: Publishing House of Moscow State Technical University "MAMI", pp. 40-43.

Shevchenko, A.V., Dolzhenko, A.V., Naumov, A.E. (2015b). Study of the strength of tube confined concrete in plastic tubes under central compression. Bulletin of Scientific Conferences, 3-4. Current Issues in Education and Science: Proceedings of the International Scientific-and-Practical Conference, November 30, 2015. Part 4. Tambov: OOO UCOM Consulting Company, pp. 172-175.

Uy, B. (2003). High-strength steel-concrete composite columns for buildings. Proceedings of the Institution of Civil Engineers Structures and Buildings, 156 (1), pp. 3-14. DOI: 10.1680/stbu.2003.156.1.3. 


\section{РЕСУРСОЭФФЕКТИВНАЯ СТЕНОВАЯ ТЕХНОЛОГИЯ ИНДИВИДУАЛЬНОГО ЖИЛИЩНОГО СТРОИТЕЛЬСТВА НА ОСНОВЕ ПЛАСТИКОТРУБОБЕТОНА}

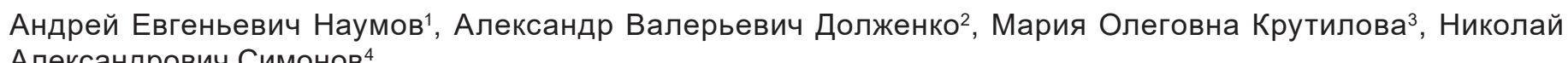
Александрович Симонов ${ }^{4}$

1,2,3,4Белгородский государственный технологический университет им. В.Г. Шухова ул. Костюкова, 46, Белгород, Россия

${ }^{3}$ E-mail: marykrutilova@gmail.com

\section{Аннотация}

Введение. В статье рассматривается экспериментальная несущая конструкция сборно-монолитных малоэтажных жилых домов с применением стеновых панелей с пластикотрубобетонными элементами. Снижение стоимости, материалоемкости и энергоемкости строительства индивидуальных жилых домов при условии обеспечения их конструктивной безопасности и долговечности может быть достигнуто оптимизацией конструктивных и технологических решений. Методы. Авторы предлагают технологию изготовления стеновых панелей, которая включает в себя индустриальное изготовление несъемных опалубок из полимерных труб и ориентированно стружечных плит, с последующей сборкой и бетонированием на месте строительства. Результаты и обсуждение. Результаты проведённых исследований были представлены межведомственной рабочей группе «Новые технологии и материалы в строительной отрасли» Департамента строительства и транспорта Белгородской области. Предлагаемая технология рекомендована к апробации на реальных площадках индивидуального жилищного строительства Белгородской агломерации, в том числе фринансируемого из бюджетных средств.

\section{Ключевые слова}

Пластикотрубобетон, трубобетон, несъемная опалубка, каркасное строительство домов, легкий бетон. 